\title{
PENGARUH EKSTRAK ASHITABA TERHADAP KADAR SERUM GLUTAMIC OXALOACETIC TRANSAMINASE DAN SERUM GLUTAMIC PYRUVIC TRANSAMINASE PADA TIKUS DENGAN LUKA BAKAR
}

\author{
${ }^{1)}$ Andrew Johan, ${ }^{2)}$ Regina Oktavia, ${ }^{3)}$ Lusiana Batubara, ${ }^{4)}$ Dwi Ngestiningsih, ${ }^{5)}$ Innawati Jusup \\ Bagian Biologi Kedokteran dan Biokimia, Fakultas Kedokteran, Universitas Diponegoro, Semarang, Indonesia. \\ JL. Prof. Dr. Soedarto no.13, Tembalang, Semarang, Indonesia \\ Email : ${ }^{1)}$ andrewjohan@fk.undip.ac.id, ${ }^{2)}$ regina.oktavia98@ gmail.com, ${ }^{3 /}$ tj.batubara@ gmail.com, ${ }^{4)}$ ngestiningsih@ fk.undip.ac.id, \\ 5)innawati.jusup@gmail.com \\ correspondence address: andrewjohan@fk.undip.ac.id
}

Kata kunci: Ashitaba; SGOT; SGPT; luka bakar

Keywords:

Ashitaba;

SGOT; SGPT;

burns injury

\section{Info Artikel}

Tanggal dikirim: 21-2-2021

Tanggal direvisi: $21-02-2021$

Tanggal diterima: 24-05-2021

DOI Artikel:

10.36341/jomis.v5i2.1697

Creative Commons Attribution-

NonCommercial-ShareAlike

4.0 International License.

\begin{abstract}
ABSTRAK
Kadar serum glutamic oxaloacetic transaminase (SGOT) dan serum glutamic pyruvic transaminase (SGPT) dapat meningkat pada kerusakan jaringan tubuh akibat cedera sedang dan cedera berat sebagai risiko dari luka bakar. Daun dari tanaman obat yang dikenal dengan nama Ashitaba mengandung banyak senyawa kimia antioksidan yang sudah diketahui dapat mengurangi kadar serum SGOT dan SGPT. Penelitian ini bermaksud untuk membuktikan bahwa dengan memberikan ekstrak dari Ashitaba dapat mengurangi kadar serum SGOT dan SGPT pada tikus yang menderita cedera luka bakar. Penelitian ini menggunakan desain posttest only control group dengan 20 tikus sebagai sampel. Semua sampel penelitian diperlakukan dengan mencapai luka bakar tingkat dua dan dibagi menjadi 2 kelompok yang berbeda, kelompok perlakuan (diberikan ekstrak Ashitaba $300 \mathrm{mg}$ / $\mathrm{KgBB}$ ) dan kelompok kontrol. Serum darah dianalisis untuk mengukur SGOT dan SGPT pada hari ke-2, ke-8 dan ke-14. Untuk analisis statistik, uji paired t test digunakan untuk menganalisis kadar serum SGOT dan SGPT. Hasil penelitian ini, kadar dari serum SGOT pada kelompok kontrol pada

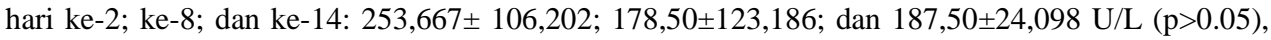
dan kadar dari serum SGOT pada kelompok perlakuan adalah 210,334 $\pm 64,615 ; 150,167 \pm 31,371$; dan 194,667 $\pm 39,596$ U/L (p>0.05). Kadar dari serum SGPT pada kelompok kontrol pada hari ke-2; ke-8; dan ke-14: 63,16 $\pm 17,11 ; 61,83 \pm 39,09 ; 51,50 \pm 10,40 \mathrm{U} / \mathrm{L}(\mathrm{p}>0,05)$ dan kadar dari serum SGPT pada kelompok perlakuan $72,16 \pm 18,98 ; 56,66 \pm 15,50 ; 59,33 \pm 13,15$ U/L tidak berbeda secara bermakna ( $>0.05)$. Hasil studi pada penelitian ini dapat disimpulkan bahwa ekstrak ashitaba dengan dosis $300 \mathrm{mg} / \mathrm{KgBB} /$ hari tidak dapat membuktikan adanya penurunan kadar serum SGOT dan SGPT pada tikus yang terkena cedera luka bakar.
\end{abstract}

\begin{abstract}
Serum glutamic oxaloacetic transaminase (SGOT) and serum glutamic pyruvic transaminase are increased in moderate and severe tissue damage caused by burn injury. Ashitaba contains many antioxidant compounds that can reduce the serum SGOT and SGPT levels. This study was proposed to prove that giving Ashitaba extract could reduce serum SGOT and SGPT levels in rats exposed to burn injury. This study used a post-test only control group design with 20 rats as samples. All research samples were treated with second degree burns and were divided into 2 different groups, the treatment group (given Ashitaba extract $300 \mathrm{mg} / \mathrm{KgBW}$ ) and control. The blood serum was analyzed for SGOT and SGPT test on the $2^{\text {nd }}, 8^{\text {th }}$ and $14^{\text {th }}$ days. For statistical analysis, paired t test was used to analyze the levels of serum SGOT and SGPT. The levels of serum SGOT in control goup on the $2^{\text {nd }}, 8^{\text {th }}$ and $14^{\text {th }}$ days were : 253,667 $\pm 106,202$; $178,50 \pm 123,186$; and 187,50 $\pm 24,098 \mathrm{U} / \mathrm{L}(\mathrm{p}>0.05)$, and the levels of serum SGOT in the treatment group were: $210,334 \pm 64,615 ; 150,167 \pm 31,371$; and 194,667 $\pm 39,596 \mathrm{U} / \mathrm{L}(\mathrm{p}>0.05)$. The Levels of serum SGPT in control group on the $2^{\text {nd }}, 8^{\text {th }}$ and $14^{\text {th }}$ days were: $63,16 \pm 17,11$; $61,83 \pm 39,09 ; 51,50+10,40 \mathrm{U} / \mathrm{L}(p>0,05)$, and the levels of serum SGPT in the treatment group were $72,16 \pm 18,98 ; 56,66 \pm 15,50 ; 59,33 \pm 13,15 \mathrm{U} / \mathrm{L}(p>0.05)$. The results of this study found that there was no significant difference in serum SGOT and SGPT levels between the control and treatment groups on $2^{\text {nd }}, 8^{\text {th }}$ and $14^{\text {th }}$ days. It was concluded that ashitaba extract administered orally in dosage $300 \mathrm{mg} / \mathrm{KgBW} /$ day for 14 days could not reduce serum SGOT and SGPT levels in rats exposed to burn injury.
\end{abstract}




\section{PENDAHULUAN}

Luka bakar merupakan cedera yang mengakibatkan kerusakan pada kulit maupun jaringan yang dibawahnya. Luka bakar dapat terjadi akibat trauma panas yang ekstrim, aliran listrik, radiasi, laser, maupun terpapar zat kimia[1]. WHO menyebutkan luka bakar sebagai masalah kesehatan secara global, terutama di negara berkembang seperti Afrika dan negara di Asia Tenggara[2]. Luka bakar dapat menyebabkan kerusakan jaringan melalui berbagai respon fisiologi dan patofisiologi. Trauma luka bakar menyebabkan terjadinya iskemia dan reperfusi jaringan. Mekanisme ini dapat berlanjut menjadi nekrosis kulit hingga kerusakan jaringan dalam. Penelitian sebelumnya menyebutkan bahwa kejadian luka bakar yang paling banyak adalah luka akibat air panas.

Tingkat keparahan luka bakar dibagi menjadi 3 derajat. Derajat I mengenai lapisan epidermis dengan eritema tanpa adanya vesikel. Derajat II terbagi menjadi dua yaitu superfisial yang mengenai lapisan epidermis hingga papila dermis dengan respon inflamasi serta vesikel dan dalam yang mengenai lapisan dermis pars retikularis. Derajat III mengenai seluruh lapisan kulit[3]. Patofisiologi penyembuhan luka bakar meliputi tiga mekanisme utama yaitu adanya trombosis akibat kerusakan vaskuler, peningkatan mediator inflamasi dan pro-apoptotic factors. Fase kedua didominasi oleh respon anti-inflamasi dimana limfosit $\mathrm{T}$ dan tiga mediator utama (sitokin IL-4, IL-10, dan TGF) memegang peranan penting[4], produksi berlebih dari mediator pro-inflamasi menyebabkan terbentuknya radikal bebas atau ROS (Reactive Oxygen Species). ${ }^{7}$ Produksi ROS yang berlebihan menyebabkan peningkatan resiko infeksi sekunder serta komplikasi seperti inflamasi, imunosupresi, dan kerusakan organ[6].
Terapi luka bakar saat ini mengandung antioksidan untuk menurunkan kadar ROS akibat luka bakar. Tanaman herbal yang memiliki komponen bioaktif dengan berbagai manfaat tentu dapat digunakan sebagai terapi alternatif luka bakar[8]. Terapi antioksidan pada hewan coba dan manusia dinyatakan memiliki manfaat dalam penyembuhan luka pada luka bakar. Penelitian sebelumnya membuktikan adanya pengaruh positif pemberian antioksidan pada pasien dengan luka bakar dimana mempercepat waktu penyembuhan luka bakar dengan pemberian kapsul berisi antioksidan (tokoferol, asam askorbat, zinc, alopurinol, melatonin, dan $N$ acetylcysteine)[9]. Astaxantin merupakan salah satu antioksidan yang aktif menurunkan kadar radikal bebas dan menghambat proses apoptosis dalam gagal ginjal akut pada tikus dengan luka bakar[10]. Minyak argan yang berasal dari Argania spinose merupakan komponen antioksidan yang terbukti lebih efektif dibandingkan sulfadiazin dalam proses penyembuhan luka bakar derajat 2 pada tikus percobaan[11].

Ashitaba merupakan tanaman herbal dari Jepang yang mulai dibudidayakan di Indonesia telah banyak dikenal sebagai terapi alternatif berbagai penyakit seperti flu, hepatitis, artritis, gangguan pencernaan, demam, dan infeksi mikroba[12]. Ashitaba memiliki banyak komponen bioaktif seperti chalcones, kumarin, dan flavonoid[13]. Penelitian sebelumnya membuktikan tidak ditemukan efek toksik pada pemberian dosis Ashitaba 1000 mg/kgBB/hari[14], dengan dosis pengobatan efektif sebesar 100-500 $\mathrm{mg} / \mathrm{kgBB} /$ hari[15]. Penelitian ini dilakukan dengan tujuan untuk memperoleh efek Ashitaba terhadap kadar SGOT dan SGPT pada tikus yang diberikan perlakuan luka bakar. 


\section{TINJAUAN PUSTAKA}

Luka bakar dianggap sebagai trauma parah karena menyebabkan terjadinya kerusakan lokal dan sistemik [16]. Proses penyembuhan luka bakar bergantung dari derajat kedalaman luka bakar. Derajat luka bakar ditentukan berdasarkan lapisan kulit dan jaringan yang terlibat : Luka bakar derajat I menyebabkan kerusakan sel epitel dimana kulit tampak eritema tanpa disertai kulit yang melepuh. Luka bakar derajat II melibatkan lapisan epidermis dalam dan lapisan dermis. Luka bakar derajat II dangkal mengenai lapisan superfisial dermis dimana kulit tampak melepuh dan terdapat respon inflamasi.. Luka bakar derajat II dalam melibatkan lapisan dermis pars retikularis dengan gambaran kerusakan jaringan. Luka bakar derajat III, disebut juga full thickness burns dimana mengenai seluruh lapisan kulit[17].

SGOT dan SGPT merupakan indikator adanya gangguan pada hepar khususnya mendeteksi adanya kerusakan sel hepatosit yang meningkat setelah luka bakar terjadi. SGOT dan SGPT dalam serum merupakan penanda terjadinya inflamasi pada hepar. Kadar serum enzim SGOT dan SGPT berkaitan dengan kerusakan hepar. SGPT ditemukan lebih dominan pada hepar walaupun juga dapat ditemukan pada ginjal, jantung, dan otot rangka dalam konsentrasi rendah, sedangkan SGOT dapat ditemukan di ginjal, hepar, jantung, otot rangka, otak, dan sel-sel darah. Oleh karena itu, SGPT merupakan indikator yang lebih spesifik menentukan derajat kerusakan hepar. SGOT dapat meningkat dengan adanya kerusakan pada organ lain seperti terjadinya infark miokard, anemia hemolitik akut, serta penyakit muskuloskeletal. Cedera luka yang parah membutuhkan transfusi akibat kehilangan darah[18].

Trauma luka bakar menyebabkan gangguan sirkulasi yang berhubungan dengan hipoksia pada jaringan. Ganguan sirkulasi ini mempengaruhi vaskularisasi hepar dimana 2/3 sirkulasi darah pada hepar berasal dari vena dan hanya $1 / 3$ yang berasal dari aorta. Adanya gangguan sirkulasi ini menyebabkan kandungan oksigen pada sinusoid menurun sehingga mengganggu aktivitas sel hepatosit. Hepar sendiri memiliki peran penting dalam merespon luka bakar dimana bertugas memproduksi protein fase akut dan memodulasi respon inflamasi sistemik. Protein fase akut berfungsi sebagai protein pengangkut mediator inflamasi dan ikut berperan dalam proses penyembuhan luka bakar. Adanya perubahan metabolisme ini akan mengganggu aktivitas sel hepatosit sehingga semakin banyak sel hepatosit yang mengalami kerusakan. Kondisi ini diperburuk dengan adanya kadar radikal bebas (ROS) berlebih dalam tubuh yang menstimulasi kerusakan sel sehingga dapat menyebabkan gangguan fungsi hepar serta mempengaruhi organ lain seperti terjadinya infark miokard, anemia hemolitik akut, maupun penyakit muskuloskeletal. Luka bakar juga dapat menyebabkan gangguan sirkulasi yang berkaitan dengan hipoksia pada jaringan[19]. Keadaan ini dapat dideteksi dengan peningkatan kadar serum enzim SGOT dan SGPT. Luka bakar di area kulit dapat menyebabkan aktivasi gen NF$\mathrm{kB}$ pada hepar dimana dapat memediasi pelepasan TNF- $\alpha$ di hepar dan berkontribusi terhadap kerusakan hepar. Pemberian melatonin dapat menurunkan kadar plasma SGOT dan SGPT secara signifikan, sementara pada kelompok kontrol didapatkan adanya peningkatan kadar serum yang signifikan Melatonin berfungsi sebagai antioksidan yang memproteksi hepar dari kerusakan akibat luka bakar dengan menginhibisi respon inflamasi yang dimediasi oleh NF- $\mathrm{B}[20]$.

Ashitaba merupakan tanaman herbal dengan nama lain Angelica keiskei yang 
termasuk dalam kelompok dari genus Umbelliferae. Secara tradisional, ashitaba telah digunakan sebagai obat diuretik, katarsis ringan, tonik, dan galactagogue. Tanaman ini disebut 'Myeong-Il Yeob' dalam bahasa Korea dan 'Ashitaba' dalam bahasa Jepang. Ashitaba dideskripsikan sebagai tanaman dengan rhizoma tebal dan pendek dengan akar yang memanjang. Batangnya kokoh, bercabang dibagian atas, tinggi 80-120 cm dan licin. Daunnya radikal pada cabang bawah, berwarna hijau, menyirip berbentuk belah ketupat dengan ukuran rata-rata $20-60 \mathrm{~cm}$. Daun yang panjang dan tidak berbulu terpisah dalam 23 celah, dengan ruas berbentuk bulat telur, panjang 5-10 cm, lebar 3-6 cm, lancip, bergerigi, dengan selubung di bagian atas. Bunganya berkelompok dengan tangkai bunga di bagian atas, mahkota bunga berjumlah 10-20 dengan tangkai berjumlah 20-40, kelopak bunga linier atau sedikit melebar dan memanjang dengan ukuran sedikit lebih panjang atau pendek dari tangkai. Komponen zat etanol dengan rumus n-hexane pada ekstrak ashitaba terbukti menghambat produksi lipopolisakarida yang terinduksi nitrit oksida dan prostaglandin $\mathrm{E}_{2}$ dengan menurunkan inducible NO synthase, protein cyclooxygenase-2 (COX-2), dan mRNA. Zat etil asetat juga menghambat produksi NO pada sel RAW 264,7 yang diaktivasi LPS [21].

Pemberian ekstrak Ashitaba dapat menginduksi peningkatan kadar serum lipoprotein termasuk lipoprotein A1 (ApoA1) dan Apo E serta menurunkan kadar trigliserida pada hepar dengan penurunan ekspresi mRNA dari sintesis Acyl-coenzyme A (CoA) pada hepar tikus dengan strokeprone spontaneously hypertensive. Komponen etil asetat dari ekstrak methanol menunjukkan adanya efek inhibisi terhadap enzim 3-hydroxy-3-methylglutaryl CoA (HMG-CoA), yang berperan dalam biosintesis kolesterol. Pemberian ekstrak
Ashitaba pada tikus dengan diet tinggi lemak menunjukkan adanya penurunan berat hepar dan peningkatan ekspresi gen pada enzim antioksidan seperti katalase dan glutathione-s-reductase. Penelitian terdahulu menyatakan bahwa pemberian ekstrak etanol mengurangi peningkatan kadar serum insulin dan trigliserida pada tikus setelah diberi minum fruktosa. Ekstrak etanol meningkatkan ekpresi gen yang terkait dengan fatty acid $\beta$-oxidation dan produksi HDL, acyl-CoA oxidase 1 (ACO1), mediumchain acyl-CoA dehydrogenase (MCAD), ATP-binding membrane cassette transporter A1 (ABCA1),dan gen ApoA1 pada tikus yang diberi makan fruktosa. Ekstrak alkohol pada Ashitaba dievaluasi kemampuannya terhadap anion superoksida dan radikal bebas 1,1-diphenyl-2-picrylhydrazyl (DPPH) dan terbukti menyebabkan penurunan radikal bebas. Efek penurunan radikal bebas lebih besar pada ekstrak daun dibandingkan ekstrak batang Ashitaba. Dengan ini, Ashitaba terbukti memiliki aktivitas antioksidan[22].

\section{Ethical Clearance:}

Penelitian ini telah disetujui oleh Komisi Etik Penelitian Kesehatan Fakultas Kedokteran, Universitas Diponegoro Semarang. Berdasarkan surat pernyataan dengan No.102/EC/H/KEPK/FKUNDIP/VII/2019.

\section{METODE}

Penelitian ini dilakukan dengan rancangan post test only with control group design, dan hasil pengukuran dari kadar serum SGOT dan SGPT dilakukan uji paired-t-test, perbedaan dinyatakan bermakna apabila diperoleh nilai $\mathrm{p}<0,05$ 


\section{Hewan Percobaan}

Dua puluh ekor tikus dimasukkan ke dalam kandang standar di Laboratorium Hewan Coba Fakultas Kedokteran Universitas Diponegoro dan diadaptasi dengan pemberian makan berupa pellet dan minum air. Suhu ruangan dipertahankan pada $29^{\circ} \mathrm{C}$, dengan kelembaban relatif $60 \%$ dan 12/12 jam siklus gelap/terang. Satu minggu sebelum perlakuan, seluruh tikus dilakukan aklitimasi dimana tikus akan dibiarkan untuk beradaptasi dalam kandang dengan mendapat makan dan minum berlebih (ad libitum). Sehari sebelum perlakuan, punggung kanan tikus dicukur sehingga ada bagian yang tidak berbulu sebesar $5 \mathrm{~cm}$ X $5 \mathrm{~cm}$. Kemudian, tikus dibius dengan menyuntikkan ketamine $0,1 \mathrm{ml} / 100 \mathrm{mg}$ secara intraperitoneal. Setelah 5 menit dianestesi, punggung kanan tikus disiram air mendidih selama 15 detik. Kemudian, tikus diacak menjadi 2 kelompok, dimana pada kelompok 1 merupakan kelompok kontrol (10 ekor tikus akan diberi pakan standar tanpa ekstrak Ashitaba) dan kelompok 2 yang merupakan kelompok perlakuan (10 ekor tikus akan diberi pakan standar dan diberikan tambahan ekstrak Ashitaba per-sonde). Ekstrak Ashitaba diberikan secara per oral selama observasi 21 hari.

\section{Pengukuran Kadar SGOT dan SGPT}

Pengambilan darah dilakukan sebanyak 3 kali, yaitu hari ke 2, 8 dan hari 14 setelah paparan air mendidih. Darah retroorbital ditampung dan segera disentrifus selama 15 menit pada $1500 \mathrm{rpm}$. Serum dipisahkan dan digunakan untuk pengukuran kadar SGOT dan SGPT menggunakan spektrofotometer. Metode yang digunakan untuk pengukuran kadar SGOT dan SGPT adalah Kinetik-IFCC (tanpa pyridoxal-5phosphate). Prinsip pemeriksaan ini adalah pembentukan senyawa asetat (pada SGOT) atau piruvat (pada SGPT) sebanding dengan oksidasi NADH menjadi NAD yang diukur dengan spektrofotometer.

\section{HASIL DAN PEMBAHASAN}

Gambaran makroskopis luka bakar dievaluasi secara keseluruhan tampak homogen dengan bentuk bulat atau sedikit oval serta tampak garis batas antara kulit yang terkena luka bakar maupun tidak.(Gambar 1).

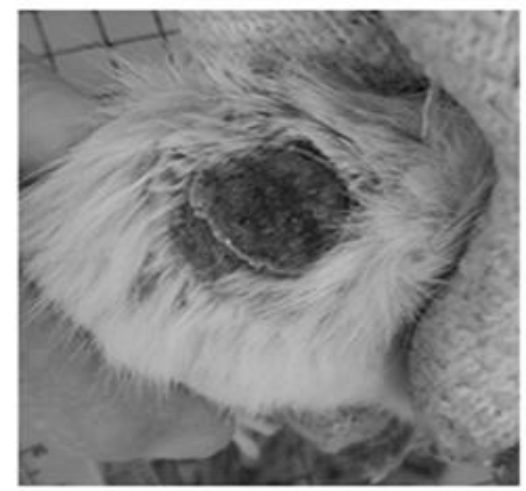

Gambar 1. Gambaran makroskopis luka bakar pada tikus percobaan.

\section{Kadar Serum SGOT}

Tabel 1. Kadar serum SGOT

\begin{tabular}{lccc}
\hline Kelompok & \multicolumn{3}{c}{ Rata-rata \pm SD $(\mathrm{U} / \mathrm{L})$} \\
\cline { 2 - 4 } & Hari 2 & Hari 8 & Hari 14 \\
\hline Kontrol & $253,667 \pm$ & $178,50 \pm$ & $187,50 \pm$ \\
& 106,202 & 123,186 & 24,098 \\
Perlakuan & $210,334 \pm$ & $150,167 \pm$ & $194,667 \pm$ \\
& 64,615 & 31,371 & 39,596 \\
\hline
\end{tabular}

Kadar serum SGOT terdapat pada (Tabel 1). Grafik data kadar serum SGOT ditunjukkan oleh Gambar 2. 


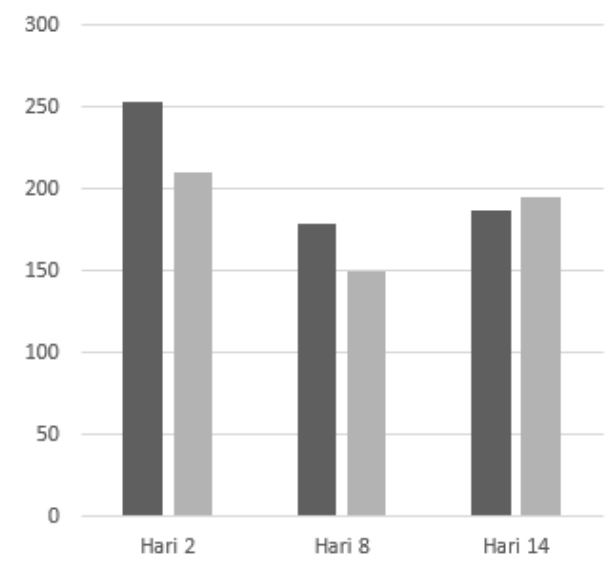

Gambar 2. Kadar serum SGOT

Diagram hitam : kelompok kontrol

Diagram abu-abu : kelompok perlakuan

Analisis statistik menggunakan uji Ttest berpasangan dilakukan untuk menemukan perbedaan bermakna diantara kelompok perlakuan hari ke- 2 dan 8 , kelompok perlakuan hari ke-8 dan 14, kelompok perlakuan hari ke-2 dan 14. Uji Ttest berpasangan juga dilakukan pada kelompok kontrol. Perbedaan dikatakan bermakna apabila nilai $\mathrm{p}<0,05$. Kadar serum SGOT yang diambil pada hari ke-2, 8, dan 14 tidak ditemukan adanya perbedaan bermakna dimana nilai $p>0,05$ pada kelompok kontrol dibandingkan kelompok perlakuan (Tabel 2).

Tabel 2. Uji T-test berpasangan pada serum SGOT

\begin{tabular}{lcc}
\hline \multicolumn{2}{c}{ Kelompok } & $\mathrm{p}$ \\
\hline Kontrol & Hari ke- 2 dan 8 & 0,345 \\
& Hari ke- 8 dan 14 & 0,345 \\
& Hari ke- 2 dan 14 & 0,183 \\
\hline Perlakuan & Hari ke- 2 dan 8 & 0,153 \\
& Hari ke- 8 dan 14 & 0,060 \\
& Hari ke- 2 dan 14 & 0,594 \\
\hline
\end{tabular}

Analisis statistik dengan uji T-test berpasangan (Tabel 2) menunjukkan tidak ditemukan perbedaan bermakna pada kelompok kontrol hari ke- 2 dan 8 $(\mathrm{p}=0,345)$, kelompok kontrol hari ke- 8 dan $14(\mathrm{p}=0,345)$, kelompok kontrol hari ke-2 dan $14(\mathrm{p}=0,183)$, kelompok perlakuan hari ke- 2 dan $8(\mathrm{p}=0,153)$, kelompok perlakuan hari ke-8 dan $14(\mathrm{p}=0,060)$, serta pada kelompok perlakuan hari ke-2 dan 14 $(p=0,594)$. Analisis statistik dengan uji independent $\mathrm{T}$-test dilakukan untuk melihat adanya perbedaan bermakna pada kelompok kontrol dan kelompok perlakuan (Tabel 3).

Tabel 3. Uji Independent T-test pada kadar SGOT

\begin{tabular}{cc}
\hline Kelompok & $\mathrm{p}$ \\
\hline Hari ke-2 & 0,413 \\
Hari ke-8 & 0,575 \\
Hari ke-14 & 0,713 \\
\hline
\end{tabular}

\section{Kadar serum SGPT}

Kadar serum SGPT paling tinggi pada hari ke-2 kelompok perlakuan dan menurun pada hari ke-8(Tabel 4).

Tabel 4. Kadar serum SGPT

\begin{tabular}{lccc}
\hline Kelompok & \multicolumn{3}{c}{ Rata-rata \pm SD (U/L) } \\
\cline { 2 - 4 } & Hari 2 & Hari 8 & Hari 14 \\
\hline Kontrol & 63,16 & 61,83 & 51,50 \\
& $\pm 17,11$ & $\pm 39,09$ & $\pm 10,40$ \\
Perlakuan & 72,16 & 56,66 & 59,33 \\
& $\pm 18,98$ & $\pm 15,50$ & $\pm 13,15$ \\
\hline
\end{tabular}

Grafik data kadar serum SGPT ditunjukkan oleh Gambar 3 berikut ini. 


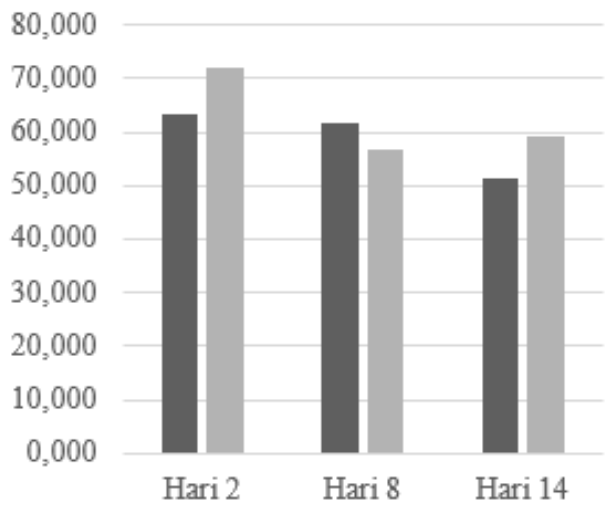

Gambar 3. Kadar serum SGPT

Diagram hitam : kelompok kontrol

Diagram abu-abu : kelompok perlakuan

Analisis statistik menggunakan uji Ttest berpasangan dilakukan untuk menentukan adanya perbedaan bermakna diantara kelompok perlakuan hari ke- 2 dan $\underline{8}$, kelompok perlakuan hari ke-8 dan 14, kelompok perlakuan hari ke-2 dan 14. Uji Ttest berpasangan juga dilakukan pada kelompok kontrol. Perbedaan dikatakan bermakna apabila nilai $p<0,05$. Kadar serum SGPT yang diambil pada hari ke-2, 8, dan 14 tidak ditemukan adanya perbedaan bermakna dimana nilai $\mathrm{p}>0,05$ pada kelompok kontrol dibandingkan kelompok perlakuan (Tabel 5).

Tabel 5. Uji T-test berpasangan pada serum SGPT

\begin{tabular}{ccc}
\hline & Kelompok & $\mathrm{p}$ \\
\hline Kontrol & Hari ke- 2 dan 8 & 0,463 \\
& Hari ke- 8 dan 14 & 0,917 \\
& Hari ke- 2 dan 14 & 0,292 \\
\hline Perlakuan & Hari ke- 2 dan 8 & 0,268 \\
& Hari ke- 8 dan 14 & 0,794 \\
& Hari ke- 2 dan 14 & 0,030 \\
\hline
\end{tabular}

Analisis statistik dengan uji T-test berpasangan (Tabel 5) menunjukkan tidak ditemukan perbedaan bermakna pada kelompok kontrol hari ke- 2 dan 8
( $\mathrm{p}=0,463)$, kelompok kontrol hari ke-8 dan $14(\mathrm{p}=0,917)$, kelompok kontrol hari ke-2 dan $14(\mathrm{p}=0,292)$, kelompok perlakuan hari ke- 2 dan $8(\mathrm{p}=0,268)$, kelompok perlakuan hari ke-8 dan $14 \quad(\mathrm{p}=0,794)$, serta pada kelompok perlakuan hari ke-2 dan 14 $(\mathrm{p}=0,030)$.Analisis statistik dengan uji independent T-test dilakukan untuk melihat adanya perbedaan bermakna pada kelompok kontrol dan kelompok perlakuan (Tabel 6).

Tabel 6. Uji Independent T-test pada kadar SGPT

\begin{tabular}{lc}
\hline Kelompok & $\mathrm{p}$ \\
\hline Hari ke-2 & 0,409 \\
Hari ke-8 & 0,335 \\
Hari ke-14 & 0,279 \\
\hline
\end{tabular}

Data yang diperoleh pada penelitian menunjukkan bahwa tidak terdapat perbedaan bermakna kadar SGOT dan SGPT antara kelompok kontrol dan kelompok perlakuan pada hari ke-2, 8, dan 14. Kadar SGOT dan SGPT dalam serum apabila terjadi peningkatan menyatakan adanya kerusakan dari jaringan hati. Pengukuran kadar SGOT dan SGPT pada penelitian ini dibatasi sampai hari ke-14, disebabkan laporan penelitian sebelum nya yang menyatakan pemberian antioksidant sudah menyatakan efek perbaikan pada hari ke-14 [23]. Setelah luka bakar, berbagai derajat kerusakan hepar terjadi yang berkaitan dengan derajat keparahan luka bakar. Mekanisme luka bakar yang menginduksi terjadinya perubahan lemak tidak dijelaskan secara rinci namun diasumsikan bahwa perubahan lemak berkaitan dengan apoptosis pada hepar. Perlemakan hepar dan edema bersifat reversibel dan sangat umum ditemukan dimana keberadaannya bergantung pada penyebab dan tingkat keparahan kerusakan sel. Luka bakar dapat menyebabkan adanya perlemakan hati yang disertai peningkatan infeksi bakteri, gagal 
hepar, dan endotoxemia[24]. Penelitian ini dilakukan di laboratorim hewan coba yang tidak memiliki ruangan steril dan tidak dapat mengamati adanya infeksi ringan pada hewan tersebut.

Segera setelah terjadi luka bakar, terjadi kerusakan hati yang berkaitan dengan peningkatan edema pada hati, dimana ditunjukkan dengan adanya peningkatan berat hepar secara signifikan pada luka bakar dibandingkan kelompok kontrol. Konsentrasi protein pada hepar menurun secara signifikan pada tikus dengan luka bakar sehingga diasumsikan bahwa peningkatan berat hepar lebih disebabkan adanya edema dibandingkan peningkatan jumlah sel hepatosit dan kadar protein. Peningkatan pembentukan edema dapat berlanjut pada kerusakan sel. Enzim hepar disekresikan pada serum antara lain SGOT dan SGPT yang merupakan indikator kerusakan hepatosit yang paling sensitif. Baik SGOT maupun SGPT berada dalam konsentrasi rendah secara normal. Namun, dengan adanya kerusakan sel akibat luka bakar atau perubahan permeabilitas membran sel, enzim ini terlepas ke sirkulasi. SGPT lebih sensitif dan spesifik sebagai indikator kerusakan pada hepar, sementara SGOT ditemukan meningkat juga pada keadaan serangan jantung dan kerusakan otot. Serum glutamat dehydrogenase juga merupakan salah satu penanda yang meningkat pada kondisi kerusakan hepar yang hebat.

Luka bakar menyebabkan kerusakan hepar akibat adanya edema, hipoperfusi jaringan, peningkatan sitokin proinflamasi, serta kematian sel dan menyebabkan peningkatan enzim hepar. Serum SGOT dan SGPT didapatkan meningkat 50\%-200\% dari nilai normal. Penelitian sebelumnya menyebutkan SGOT dan SGPT meningkat dan mencapai puncak pada hari pertama setelah terjadi luka bakar. Pada kondisi regenerasi hepatik, seluruh enzim turun ke nilai normal pada fase akut penyembuhan. Kelemahan pengukuran enzim hepar adalah adanya kemungkinan peningkatan kadar akibat faktor lain, seperti adanya penyakit hepar yang dapat meningkatkan kadar SGOT dan SGPT. Kerusakan persisten hepar akibat sepsis juga dapat menyebabkan peningkatan kadar SGOT dan SGPT sehingga penelitian dengan pengukuran kadar SGOT dan SGPT harus dilakukan secara teliti. Infeksi oleh bakteri dapat terjadi pada lokasi yang luka akibat kontaminasi lingkungan maupun adanya transmisi bakteri oleh peneliti pada saat proses penyembuhan luka juga dapat mempengaruhi hasil penelitian [25].

\section{Antioksidan dalam proses penyembuhan luka bakar}

Antioksidan menurunkan radikal bebas seperti reactive oxygen and nitrogenoxygen species yang menyebabkan respon stres retikulum endoplasma, gangguan mitokondria, dan transkripsi faktor proinflamasi. Antioksidan dapat menurunkan kematian sel, apoptosis jaringan, dan kegagalan organ pada luka bakar yang hebat. Antioksidan bekerja dalam menghambat kerusakan sel, melindungi sirkulasi mikrovaskuler, mengurangi peroksidasi lipid pada jaringan, meningkatkan curah jantung, menurunkan volume cairan yang diperlukan untuk resusitasi, serta mempercepat proses penyembuhan luka bakar. Pasien yang mendapatkan terapi disertai suplemen yang mengandung antioksidan dinyatakan terbukti menurunkan penanda mediator inflamasi akibat luka bakar, dimana dikaitkan dengan peningkatan respon penyembuhan, jangka waktu rawat inap yang lebih pendek, serta meningkatkan clearance bakteri. Pemberian suplemen antioksidan per oral seperti asam askorbat, glutathione, dan vitamin A dapat dikombinasikan sudah dilakukan untuk meningkatkan kelangsungan hidup pada pasien luka bakar[26]. Keterbatasan 
penelitian ini adalah hanya digunakan satu dosis (300 $\mathrm{mg} / \mathrm{kgBB} / \mathrm{hari}$ ) dimana dosis tersebut belum merupakan dosis efektif sehingga diusulkan adanya penelitian lebih lanjut dengan variasi dosis.

\section{KESIMPULAN}

Ekstrak Ashitaba dengan dosis 300 $\mathrm{mg} / \mathrm{kgBB} /$ hari yang diberikan secara per oral selama 14 hari terbukti tidak dapat menurunkan kadar serum SGOT dan SGPT pada tikus Sprague Dawley yang di induksi luka bakar.

\section{DAFTAR PUSTAKA}

1. Hettiaratchy S, Dziewulski P. ABC of burns: pathophysiology and types of burns. BMJ. 2004 Jun

12;328(7453):1427-9. https://doi.org/10.1136/bmj.328.745 3.1427

2. WHO Burn injury. https://www.who.int/news-room/factsheets/detail/burns

3. Tiwari VK. Burn wound: How it differs from other wounds? Indian J Plast Surg. 2012 May;45(2):364-73. https://doi.org/10.4103/09700358.101319

4. Sehirli O, Sener E, Sener G, Cetinel S, Erzik C, Yeğen BC. Ghrelin improves burn-induced multiple organ injury by depressing neutrophil infiltration and the release of pro-inflammatory cytokines. Peptides. 2008;29:1231-40. https://doi.org/10.1016/j.peptides.20 08.02.012

5. Wang S, Huang Q, Guo J. Local thermal injury induces general endothelial cell contraction through p38 MAP kinase activation. APMIS. 2014;122:832-41. https://doi.org/10.1111/apm.12226
6. Nielson CB, Duethman NC, Howard JM, Moncure M, Wood JG. Burns: Pathophysiology of Systemic Complications and Current Management. J Burn Care Res. 2017 $\mathrm{Jan} / \mathrm{Feb}$;38(1):e481. https://doi.org/10.1097/BCR.000000 0000000355

7. Lin PH, Sermersheim M, Li H, Lee PHU, Steinberg SM, Ma J. Zinc in Wound Healing Modulation. Nutrients. 2017 Dec 24;10(1):16. https://pubmed.ncbi.nlm.nih.gov/292 95546

8. Nielson CB, Duethman NC, Howard JM, Moncure M, Wood JG. Burns: Pathophysiology of Systemic Complications and Current Management. J Burn Care Res. 2017; 38(1): e469-e481. https://pubmed.ncbi.nlm.nih.gov/271 $\underline{83443}$

9. Sahib AS, Al-Jawad FH, Alkaisy AA. Effect of antioxidants on the incidence of wound infection in burn patients. Ann Burns Fire Disasters. 2010;23(4):199-205. https://www.ncbi.nlm.nih.gov/pmc/ar ticles/PMC3188280

10. Guo SX, Zhou HL, Huang CL, You CG, Fang Q, Wu P, Wang XG, Han $\mathrm{CM}$. Astaxanthin attenuates early acute kidney injury following severe burns in rats by ameliorating oxidative stress and mitochondrialrelated apoptosis. Mar Drugs. 2015 Apr 13;13(4):2105-23. https://doi.org/10.3390/md13042105

11. Avsar U, Halici Z, Akpinar E, Yayla M, Avsar U, Harun U, Harun U, Hasan Tarik A, Bayraktutan Z. The Effects of Argan Oil in Seconddegree Burn Wound Healing in Rats. Ostomy Wound Manage.2016 Mar;62(3):26-34. 
https://pubmed.ncbi.nlm.nih.gov/269 78857

12. Caesar LK, Cech NB. A Review of the Medicinal Uses and Pharmacology of Ashitaba. Planta Med. 2016 ;82(14):123645.https://www.thiemeconnect.com/products/ejournals/pdf/ 10.1055/s-0042-110496.pdf

13. Hisatome T, Wachi Y, Yamamoto Y, Ebihara A, Ishiyama A, Miyazaki H. Promotion of Endothelial Wound Healing by the Chalcones 4hydroxyderricin and Xanthoangelol, and the Molecular Mechanism of This Effect. J Sustain Agr. 2017; 12: 25-33.

https://www.jstage.jst.go.jp/article/jd sa/12/1/12_25/_pdf/-char/en

14. Maronpot RR. Toxicological assessment of Ashitaba Chalcone. Food Chemical Toxicol. 2015; 77: 111-19.

https://pubmed.ncbi.nlm.nih.gov/255 76957

15. Zhang XG, Li XM, Zhou XX, Wang Y, Lai WY, Liu Y, et al. The Wound Healing Effect of Callicarpa Nudiflora in Scalded Rats. Evid Based Complement Alternat Med. 2019; 2019: 1-8. https://pubmed.ncbi.nlm.nih.gov/311 $\underline{86655}$

16. Chen MM, Zahs A, Brown MM, Ramirez L, Turner JR, Choudhry MA, Kovacs EJ. An alteration of the gut-liver axis drives pulmonary inflammation after intoxication and burn injury in mice. Am J Physiol Gastrointest Liver Physiol. 2014 Oct 1;307(7):G711-8. https://doi.org/10.1152/ajpgi.00185. 2014

17. Jeschke MG, Finnerty CC. The hepatic response to thermal injury. Total Burn Care. 2012;4:651-65. https://www.ncbi.nlm.nih.gov/pmc/ar ticles/PMC2710295

18. Posluszny JA Jr, Conrad P, Halerz M, Shankar R, Gamelli RL.

Classifying transfusions related to the anemia of critical illness in burn patients. J Trauma. 2011

Jul;71(1):26-31. https://doi.org/10.1097/TA.0b013e31 81f2d9ed

19. Xing D, Liu L, Marti GP, Zhang X, Reinblatt M, Milner SM, Harmon JW. Hypoxia and hypoxia-inducible factor in the burn wound. Wound Repair Regen. 2011 MarApr;19(2):205-13. https://pubmed.ncbi.nlm.nih.gov/213 $\underline{62088}$

20. Bekyarova G, Apostolova M, Kotzev I. Melatonin protection against burninduced hepatic injury by downregulation of nuclear factor kappa $B$ activation. Int $\mathbf{J}$ Immunopathol Pharmacol. 2012 Jul-Sep;25(3):5916.

https://pubmed.ncbi.nlm.nih.gov/230 58009/

21. Chang HR, Lee HJ, Ryu J-H. Chalcones from Angelica keiskei attenuate the inflammatory responses by suppressing nuclear

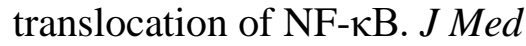
Food. 2014;17:1306-1313. https://pubmed.ncbi.nlm.nih.gov/253 69132/

22. Kil YS, Pham ST, Seo EK, Jafari M. Angelica keiskei, an emerging medicinal herb with various bioactive constituents and biological activities. Arch Pharm Res. 2017 Jun;40(6):655-675. https://doi.org/10.1007/s12272-0170892-3

23. Jang JK, Lee OS, Kang TJ, Lim SC. Wound healing effect of cuttlebone extract in burn injury of rat. Food Sci 
Biotechnol. 2013;22(1):99-105. https://link.springer.com/article/10.1 007/s10068-013-0054-4

24. Lachiewicz AM, Hauck CG, Weber DJ, Cairns BA, van Duin D. Bacterial Infections After Burn Injuries: Impact of Multidrug Resistance. Clin Infect Dis. 2017 Nov 29;65(12):2130-2136. https://pubmed.ncbi.nlm.nih.gov/291 94526/

25. Chen MM, Zahs A, Brown MM, Ramirez L, Turner JR, Choudhry MA, Kovacs EJ. An alteration of the gut-liver axis drives pulmonary inflammation after intoxication and burn injury in mice. Am J Physiol Gastrointest Liver Physiol. 2014 Oct 1;307(7):G711-8.

https://pubmed.ncbi.nlm.nih.gov/251 04501/

26. Kurmis R, Greenwood J, Aromataris E. Trace Element Supplementation Following Severe Burn Injury: A Systematic Review and MetaAnalysis. J Burn Care Res. 2016 May-Jun;37(3):143-59. https://pubmed.ncbi.nlm.nih.gov/260 $\underline{56754 /}$ 